\title{
Life Cycle Cost Analysis of Road Pavements
}

\author{
${ }^{1}$ Tejas Gaikwad, ${ }^{2}$ Lalesh Rawade Patil, ${ }^{3}$ Ravindra Zinjade, \\ ${ }^{4}$ Vaibhav Sisode, ${ }^{5}$ Sangram Rajput, ${ }^{6}$ Shilpa Mahajan \\ $1,2,3,4,5$ Graduate Student \\ ${ }^{6}$ Assistant Professor \\ 1,2,3,4,5,6 Department of Civil Engineering, G. S. Moze Engineering College, \\ SPPU University, Pune, Maharashtra, India
}

\begin{abstract}
LCCA for the Road - It is the process for determining the total cost of road pavements including initial construction cost, operational and maintenance cost. To reduce the life cycle cost of road pavements it is necessary to deal with the initial cost and need to learn preventive maintenance of pavements. The proper implementation of preventive maintenance techniques for road pavements can extend the life of a pavement structure in a cost-effective manner. Different Researchers in the field of road construction have found that Economic and Sensitivity Analysis can be used as methods to analyze LCCA results found by NPV and IRR with different affecting input parameters. This paper describes the procedure of estimation of different costs required for LCCA of roads, and also the methodology of LCCA is being described with suitable road data.
\end{abstract}

Index Terms-LCCA of road pavements, preventive maintenance, NPV, IRR, maintenance cost, user cost

\section{INTRODUCTION}

In any economy transport infrastructure act like a baseline to ensure continues smooth flow of movability of public and goods as input and output from all economic sectors

Roads are among the most important public assets in all countries. Road improvements bring immediate and sometimes dramatic benefits to road users through improved access to hospitals, schools, and markets; improved comfort, speed, and safety; and lower vehicle operating costs for these benefits to be sustained, road improvements must be followed by a well-planned program of maintenance

LCCA is a process of evaluating the economic performance of a structure over its entire life.

LCCA is especially useful when project alternatives that fulfil the same performance requirements, but differ with respect to initial costs and operating costs, have to be compared in order to select the one that maximizes net savings.

LCCA for road is required because roads, and means of transport, make a crucial contribution to economic development. Poorly maintained roads constrain mobility, significantly raise vehicle operating costs, increase accident rates and their associated human and property costs, and are needed to be deal.

To reduce the overall cost of the road right from construction cost to its repair cost the high quality material constructions with regular preventive maintenance is required "Preventive Maintenance: Work undertaken that preserves the existing pavement, retards future deterioration, and improves the functional life without substantially increasing the structural capacity

Neglected roads steadily become more difficult to use, resulting in increased vehicle operating costs (more frequent repairs, more fuel use) and a reluctance by transport operators to use the roads. This imposes a heavy burden on the economy: as passenger and freight services are curtailed, there is a consequent loss of economic and social development opportunities

\section{DIFFERENT COST OF LCCA OF ROAD PAVEMENT}

Two groups of people are affected by Roads with respect money, the first group of people is of organizations/institutes constructing and maintaining roads and the second group of people is people using the roads. So we need to deal with two costs incurred first is construction cost and second is user cost.

1. Construction and Maintenance cost (C\&M cost)

(Direct costs) includes the following costs

- Reconnaissance Survey

- Traffic Surveys

- Topographic Surveys

- Soil And Materials Investigations

- Geo-Technical Investigations

- Carrying Out Hydraulic Surveys And Hydrological Studies

- Land Acquisition

- initial construction

- maintenance cost

- rehabilitation costs

2. User Cost includes the following costs (Indirect costs)

- Vehicle operating costs

- User delay costs

- Accidents cost includes both for fatality, non-fatal injury, and property damage only.

\section{COST ESTIMATION PROJECT}

1. The rates of various items of construction work have been analysed as per procedure laid down in the "MORT\&H Standard Data Book"-2017 (Fifth Revision) and guidelines set therein. 
2. The Rates of Hire Charges for Machinery approved by Chief Engineer should be considered.

3. The rates of cement, Steel, and Bitumen which have been provided as per current market rates.

4. Computation of quantities of earthwork and other components of road worked out from TCS drawings and computed.

5. Computation of cost of bridges from their General Arrangement Drawings by working out the Quantities.

6. Estimation of cost of land acquisition, resettlement and rehabilitation costs, utility relocation and environmental mitigation measures as per the detailed assessment of their costs.

7. Estimation of allowances for contingencies and supervision charges as a percentage of the civil cost.

8. Estimation of the total project cost.

\section{METHODOLOGY OF LCCA OF ROAD PAVEMENTS}

1. The performance period and activity timing should be calculated.

2. Total Costs associated with all available alternatives should be calculated.

3. Net Present Value (NPV) and IRR must be calculated

4. Equivalent Uniform Annual Costs (EUAC) must be calculated

5. After initial NPV's are calculated for all available alternatives should be analysed

6. Analysis should involve an economic analysis and a risk sensitivity analysis

Sensitivity analysis is a method for predicting the outcome of a decision if a situation turns out to be different compared to the key predictions.

Sensitivity analysis helps decision makers choose the alternative

Sensitivity analysis typically has five (5) steps:

1. Identify key cost drivers, ground rules, and assumptions for sensitivity testing;

2. Re-estimate the total cost by choosing one of these cost drivers to vary between two set amounts; for example, maximum and minimum or performance thresholds;

3. Document the results;

4. Repeat 2 and 3 until all factors identified in step 1 have been tested independently;

5. Evaluate the results to determine which drivers affect the cost estimate most.

Two critical factors could affect the viability of the project and these are the Cost and benefits Sensitivity analysis should be carried out with respect to adverse changes in the costs and benefits.

- $\quad$ Base case;

- $15 \%$ increase in construction cost;

- $50 \%$ reduction in time benefits;

- $15 \%$ decrease in total benefits;

- $15 \%$ increase in cost and a $15 \%$ decrease in benefits.

The results of the sensitivity analysis should indicate whether the project roads are economically viable with adverse variations in costs and benefits or not.

\section{DATA COLLECTED}

\begin{tabular}{|l|l|l|l|l|}
\hline Sr no & Road name & length & Cost per km & Total cost \\
\hline 1 & Chitrangi-Kasar Road & 40.39 & 17.64 & 712.47 \\
\hline 2 & Mahua-Chuwahi Road & 49.10 & 20.96 & 1029.136 \\
\hline 3 & Dabra-Harsi Road & 62.10 & 25.72 & 1597.212 \\
\hline 4 & Ujjain-Makhsi Road & 36.34 & 23.11 & 839.81 \\
\hline 5 & SH 78 (Bihta-Sarmera) & 100 & 51.88 & $5,188.4$ \\
\hline 6 & SH 81 (Sakkadi-Nasrigunj) & 85 & 33.33 & $2,893.8$ \\
\hline 7 & SH 90 (Mohammadpur-Chapra) & 69 & 49.98 & $3,234.0$ \\
\hline 8 & SH 91 (Birpur-Udakishunganj) & 102 & 50.62 & $5,382.6$ \\
\hline
\end{tabular}

\section{DATA ANALYSED}

\begin{tabular}{|l|l|l|l|}
\hline Sr no & Road name & IRR $(\%)$ & NPV(Rs million) \\
\hline 1 & Chitrangi-Kasar Road & 15.64 & 142.84 \\
\hline 2 & Mahua-Chuwahi Road & 17.56 & 427.58 \\
\hline
\end{tabular}




\begin{tabular}{|l|l|l|l|}
\hline 3 & Dabra-Bhitarwar-Harsi Road & 22.96 & 953.38 \\
\hline 4 & Ujjain-Makhsi Road & 21.91 & 779.91 \\
\hline 5 & State Highway 78 (Bihta-Sarmera) & 17.1 & 1896.4 \\
\hline 6 & State Highway 81 (Sakkadi-Nasrigunj) & 28.8 & 3596.2 \\
\hline 7 & State Highway 90 (Mohammadpur-Chapra) & 19.1 & 1794.5 \\
\hline 8 & State Highway 91 (Birpur-Udakishunganj) & 20.9 & 2572.7 \\
\hline
\end{tabular}

Sensitivity Analysis

1. Economic Internal Rate of Return (\%)

\begin{tabular}{|l|l|l|l|l|l|}
\hline $\begin{array}{l}\text { Project } \\
\text { Road }\end{array}$ & Base case & $\begin{array}{l}\text { Increase in Cost by } \\
10 \% \\
\text { (S1) }\end{array}$ & $\begin{array}{l}\text { Reduction } \\
\text { in Benefits by 10\% } \\
\text { (S2) }\end{array}$ & $\begin{array}{l}\text { Increase in Cost and } \\
\text { Reduction } \\
\text { in Benefits by 10\% ( } \\
\text { S3) }\end{array}$ & $\begin{array}{l}\text { 1-Year Delay in Construction } \\
\text { (S4) }\end{array}$ \\
\hline $\begin{array}{l}\text { Mahua- } \\
\text { Chuwahi } \\
\text { Road }\end{array}$ & 17.56 & 16.24 & 16.11 & 14.85 & 16.92 \\
\hline
\end{tabular}

2. Net Present Value (Rs million)

\begin{tabular}{|l|l|l|l|l|l|}
\hline $\begin{array}{c}\text { Project } \\
\text { Road }\end{array}$ & Base case & $\begin{array}{l}\text { Increase in Cost by } \\
10 \%\end{array}$ & $\begin{array}{l}\text { Reduction } \\
\text { in Benefits by 10\% }\end{array}$ & $\begin{array}{l}\text { Increase in Cost and Reduction } \\
\text { in Benefits by 10\% }\end{array}$ & 1-Year Delay in Construction \\
\hline $\begin{array}{l}\text { Mahua- } \\
\text { Chuwahi } \\
\text { Road }\end{array}$ & 427.58 & 348.20 & 305.12 & 225.75 & 387.93 \\
\hline
\end{tabular}

\section{CONCLUSION}

- The results of the sensitivity analysis show that Mahua-Chuwahi road have an EIRR higher than 12\% in all sensitivity tests, indicating the economic viability within the range of variability anticipated.

- The values of IRR are more than $12 \%$ desirable rate of return so it can be conclude that this proposed alternative is best one.

- Maintenance Cost can be reduced by Preplanning and implementing Preventive maintenance technique.

\section{REFERNCES}

1. Rob Harrison, Steve Waalkes, and William James Wilde-Project 0-1739: A Life Cycle Cost Analysis of Rigid Pavements

2. Audu HAP, Aniekwu AN and Oghorodje EE-Life Cycle Cost Analysis (LCCA) Delivery Model for an Urban Flexible Pavement
3. Shah Yogesh U, Jain S. S and Tiwari Devesh-Adaptation of HDM-4 Tool for Strategic Analysis of Urban Roads Network

4. Peyman Babashamsi, Nur Izzi Md Yusoff, Halil Ceylan Evaluation of pavement life cycle cost analysis: Review and analysis

5. Jan Mikolaj, Lubos Remek-Life Cycle Cost Analysis - Integral Part of Road Network Management System

6. (FHWA's)- Life Cycle Cost Analysis Primer

7. H. A. P. Audu, E.Oghorodje and D. E. Oviri-Sensitivity analysis on flexible roads pavement life cycle cost model

8. Rajanish Kumar, Shrey Jain-Final Feasibility Study Report Volume I - Main Report March 2017.

9. Kashmira Rasane, Harshita Ambre-A STUDY ON LIFE CYCLE COST ANALYSIS FOR ROADS (2019)

10. Asian Development Bank adb.org.in- Madhya Pradesh District Connectivity Sector Project (RRP IND 47270)

11. Parise Venkata Ravi Teja, Pagidimari Gopi- LIFE CYCLE COST ANALYSIS OF LONG LASTING PAVEMENTS (2017) 